\title{
Global helse og utenrikspolitikk
}

Min far hadde meslinger. Jeg ble vaksinert mot virus i nabolaget. Mine barn er vaksinert mot meslingvirus fra den andre siden av kloden.

Vi må ta omkamp om vårt forbud mot alkoholreklame i Brussel.

Disse to eksemplene vitner ikke bare om medisinsk framgang i en verden som stadig blir mindre, men også om at kampen for norsk folkehelse ikke bare foregår i kommunestyrer og Storting, men i stigende grad må vinnes i Brussel, Genève og New York. Det er dette global helse dreier seg om.

Vi har gjort global helse til et sentralt tema i norsk utenrikspolitikk. I vår bistand, som er rettet mot de fattigste landene, har regjeringen gitt kvinne- og barnehelse prioritet. Statsministeren leder dette arbeidet. Helt siden 2005 har vi drevet aktivt politisk pådriverarbeid på høyeste plan, bl.a. gjennom et nettverk av globale ledere. Dette ga full uttelling i fjor: $\mathrm{G} 8$ hadde det som topprioritet i Canada, og senere i New York lanserte FNs generalsekretær «Every Woman Every Child» med bred støtte fra fattige og rike land, frivillige organisasjoner, privat sektor, fagmiljøer og kunnskapsmiljøer.

Dette initiativet peker framover i en verden i endring - med rask økonomisk vekst i utviklingsland og stagnasjon i den rike verden. Det er tuftet på nasjonalt ansvar med konkrete forpliktelser fra statslederne, ansvarliggjøring av alle aktørene og innovasjon.

Selv var jeg med i en kommisjon som laget retningslinjer for resultatfokus og ansvarliggjøring av forpliktelser fra alle engasjerte grupper. Kommisjonens rapport ble lansert i FN i september med en handlingsplan og med opprettelsen av en uavhengig ekspertgruppe for kvalitetssik- ring av resultater og ressursrapportering. Nesten seks milliarder mennesker har nå mobiltelefon. Mobiltelefoni har klart det ingen har klart før - nemlig å skape et marked blant de fattigste to milliardene mennesker i verden. Dette gir helt nye muligheter for kvinner til tilgang på helseinformasjon, kontakt med helsepersonell, overføring av data, bilder (som ultralyd) og penger, som for eksempel transportstøtte til en fødende kvinne. Nye data tyder på at takten i framgangen for mødre- og barnehelse øker.

Norge er også en viktig bidragsyter til global helse, med over 3 milliarder kroner årlig. De største bidragene går til vaksinealliansen GAVI, Det globale fondet mot AIDS, malaria og tuberkulose, Verdens helseorganisasjon, UNICEF og FNs befolkningsfond (UNFPA). Denne innsatsen bygger på grunnpilarer i norsk utenrikspolitikk: Kampen for likestilling og menneskerettighetene.

Dette arbeidet er ikke blitt lettere i de siste årene. Ofte er det blitt omkamp om tidligere inngåtte avtaler og prinsipper. Dette gjelder spesielt reproduktiv helse, men også betydningen av tobakksavgifter for å redusere tobakksbruken. Det krevde betydelig norsk innsats å få dette med under forhandlingene om livstilssykdommer i FN, selv om det er nedfelt i tobakkskonvensjonen fra 2003, som 173 land har underskrevet.

Det er viktig å forstå bakteppet for denne utviklingen. Vi lever i en urolig tid. Japan, EU og USA er inne i en økonomisk krise som trekker ut. Egen økonomi får førsteprioritet. En ser innover og er mindre villig til å inngå internasjonale avtaler, spesielt slike som krever forpliktelser fra offentlig eller privat sektor. De nye stormaktene i rask økonomisk vekst, som Brasil, India og Kina, lar tiden arbeide for seg og er mer opptatt av å få sin rettmessige plass i den nye verdensorden enn å inngå internasjonale avtaler. Dette skaper spenninger. Norge har i denne situasjonen fått større rom og rolle i internasjonalt samarbeid. Dette vil vi utnytte.

Vi lever i en krevende tid for å få de regionale og globale avtalene som trengs for å fremme norsk folkehelse. Men vi har også lyktes, som denne våren - med regelverket for avtaler om influensavirus som forårsaker nye epidemier og pandemier. Det viste betydningen av å ha internasjonale nettverk som ser på sammenhengene mellom utenrikspolitikk og helse, nettverk som vi har bygd opp over flere år og som går på tvers av etablerte maktgrupperinger.

I denne situasjonen er tiden inne for å utvikle en langsiktig strategi for å sikre norsk folkehelse gjennom nødvendige internasjonale avtaler. Denne strategien vil bygge på fire pilarer:

- Et sterkt faglig og vitenskapelig grunnlag for de saker vi fremmer

- En dyp forståelse av hva hindringene er og det internasjonale aktørbildet

- Konkrete planer for hvordan hindringene kan overkommes på grunnlag av innsikt og erfaringer fra utenrikstjenesten og helsetjenesten

- En tverrfaglig internasjonalt rettet innsats basert på tett samarbeid mellom Helse- og omsorgsdepartementet og Utenriksdepartementet

Jeg vil gjerne utfordre helsepersonell til dialog, engasjement og innspill i dette potensielt viktige bidrag til norsk folkehelse.

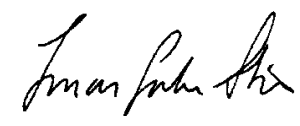

